\title{
BORON ADSORPTION AND DESORPTION STUDY: CORRELATION BETWEEN SOIL PROPERTIES, AVAILABLE BORON AND THE ADSORPTION ISOTHERM PARAMETERS
}

\author{
ANGEL RUPHINA ${ }^{1} \&$ SURESH $^{2}$
}

${ }^{1}$ PG Student, Department. of Soil Science \& Agricultural Chemistry, AC \& RI, Killikulam, TNAU, Coimbatore, Tamil Nadu, India ${ }^{2}$ Professor \& Head, Department of Soil Science \& Agricultural Chemistry, AC \& RI, Killikulam, TNAU, Coimbatore, Tamil Nadu, India ABSTRACT

Boron is one of the essential micronutrients to almost all the crops. Interest in boron research has been increasing due to its wide role and increasing deficiencies in many parts of the world. Boron adsorption and desorption study helps to have a detailed knowledge on boron availability, its adsorption and retention. Hence, the adsorption study was carried out using five major soil series which covers the major areas of Tamirabharani tract of TamilNadu, India. Varying concentrations of boron were added to the soils and their ability to adsorb as well the desorption with time has been studied. The study on the correlations between available boron and other soil properties were analyzed, which showed a high positive correlation with $\mathrm{pH}\left(r^{2}=0.87\right), \mathrm{EC}\left(r^{2}=0.84\right)$, Clay $\left(r^{2}=0.78\right), O C\left(r^{2}=0.74\right)$ and a negative correlation with silt $\left(r^{2}=0.69\right)$ and sand $\left(r^{2}=0.78\right)$. The adsorbed Born were fitted into Frendulich and Langmuir adsorption isotherm equations, which revealed that the Frendulich isotherm was best suited to Boron adsorption than Langmuir adsorption isotherm.The correlation between isotherm parameters of Frendulich and Langmuir with the soil properties were also studied. Boron desorption study revealed that the adsorption showed inverse relationship with boron desorption. Desorption of boron is initially rapid and it is slowed down as time proceeds.

KEYWORDS: Boron, Adsorption, Desorption\& Isotherm equations

Received: May 06, 2020; Accepted: May 26, 2020; Published: Jun 10, 2020; Paper Id.: IJASRAUG20201

\section{INTRODUCTION}

Boron is one of the essential micronutrients and its essentiality was first proven by Warrington. Various roles of boron in plant system includes sugar transport, protein and carbohydrate metabolism and so on. Boron is found to increase the quality parameters of most of the fruit crops and even reduction in chaffiness in cereal crops like rice and wheat. Since boron has important role in the reproductive growth of many crops, the study of availability is found essential. Boron deficiency has been reported at different parts of the world. Boron is the second most deficient nutrient in India. Nearly $33 \%$ of Indian soils are found to be boron deficient, whereas certain parts of the country face boron toxicity due to the high concentration of boron in the irrigation water as well as in the groundwater.

There is a narrow limit between boron deficiency and toxicity, and hence proper study and cautious fertilization program is absolutely essential. Adsorption and desorption studies are used to indicate the availability of any nutrient. Boron availability can also be studied by adsorption and desorption behavior of boron in soil. The study on boron has been lacking in India, especially in Tamil Nadu, and hence attracts a number of scientists to choose this field of study. The present study was conducted at Tamirabharani command area of Tamil Nadu, India where intensive agriculture(rice and 
banana) is carried out without the application of micronutrients. The available Boron status of Tamrabharani command area is found to be in deficient status. Boron availability is influenced by number of soil properties like pH, EC, CEC, organic carbon and also the textural composition. Boron availability increases with increase in $\mathrm{pH}$, and it is negatively influenced by sand content of the soil. Boron availability is also influenced by the organic matter, hydroxides of iron and aluminium and calcareousness. Available boron can be estimated by using various extractants like $\mathrm{CaCl}_{2}$, hot water, $\mathrm{Mechlich}$ 's reagents etc. Besides all those, the hot water extracted Azomethane $\mathrm{H}$ method of boron estimation was found suitable. Various adsorption isotherm equations have been developed by different scientists, and the popular among them are Frendulich and Langmuir adsorption isotherms. Frendulich isotherm has been found more suitable than the Langmuir adsorption isotherm. The relationship between the isotherm parameters and the soil properties as well as the available boron, has been studied to evaluate the optimum dose of application of boron in relation to soil properties.

\section{MATERIALS \& METHODS}

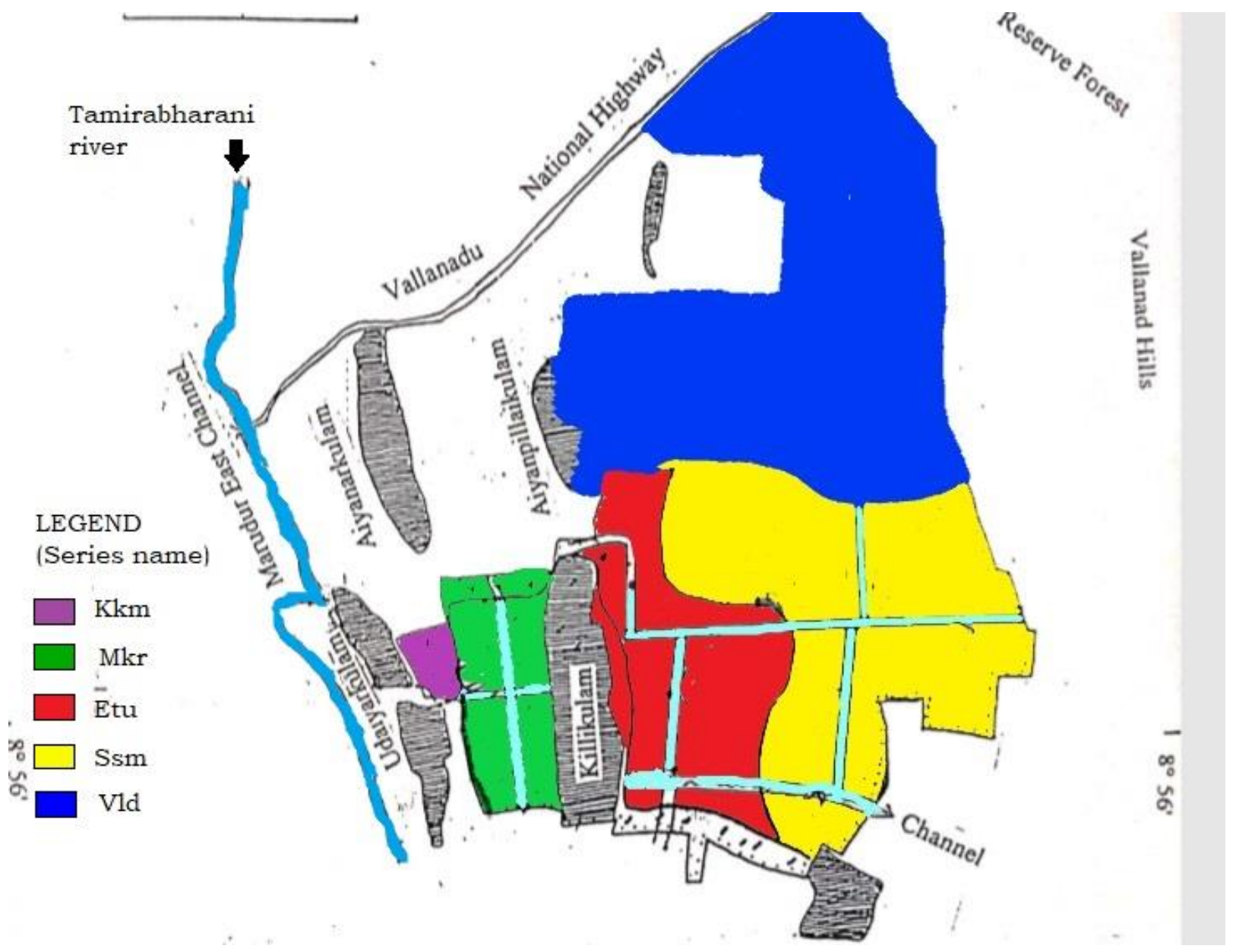

Figure 1: Map of the Study Area, Showing Series Location and Delineations.

Surface soil samples (10-20 cm depth) were collected from five major soil series of Tamirabarani tract viz., Manakarai(Mkr), Killikulam(Kkm), Ezhuthaniyuthu(Etu), Vallanad(Vld) and Sivasubramanyapuram(Ssm). Various soil properties were determined, which includes texture by International pipette method, $\mathrm{pH}$ and EC by potentiometric and conductometric methods, CEC by Nuetral normal ammonium acetate method and organic carbon by Walkley and Black method and organic 
Boron Adsorption and Desorption Study: Correlation between Soil Properties, Available Boron and the Adsorption Isotherm Parameters

matter content was derived from organic carbon content. Available Boron content in the soil is estimated by using Hot water soluble Azomethane- H method (Gupta, 1967).

Adsorption and desorption behavior of boron in the soil was estimated by employing the method outlined by Elrashidi \& O'Connor(1982) with few modifications. Ten grams of soil samples were added with 20ml 0f $0.01 \mathrm{M}$ CaCl2 solution containing varying concentrations of boron viz., $0,2.5,5,10,20,30,40,50 \mathrm{ppm}$ of boron as boric acid. The contents were taken in centrifuge tubes and were shaken in wrist action shaker (occasional shaking) for 24 hrs and then centrifuged. Supernatant were collected and $10 \mathrm{ml}$ of supernatant was filtered through Whatman No. 40 filter paper and available Boron was estimated by spectophotometric method using Azomethane $\mathrm{H}$ reagent. Amount of Boron adsorbed was identified by calculating the difference between the amount of B in initial solution and that in the final solution after shaking. The adsorption isotherms of Frendulich and Langmuir were used to describe the adsorbed Boron.

Freundlich Equation: $x=a^{1 / n}$

$\mathrm{X}$ - amount of adsorbed B ( $\mathrm{mg} \mathrm{kg}^{-1}$ soil)

c- the equilibrium B concentration $\left(\mathrm{mg} \mathrm{L}^{-1}\right)$.

Two parameters, a and $1 / \mathrm{n}$, were calculated using the linear transformation $\log \mathrm{x}=\log \mathrm{a}+(1 / \mathrm{n}) \log \mathrm{c}$.

\section{Langmuir Equation: $x=k$ b c/(1 + kc)}

b - maximum monolayer B adsorption capacity $\left(\mathrm{mg} \mathrm{kg}^{-1}\right.$ soil)

$\mathrm{k}$ - the affinity coefficient that reflects the relative rate of adsorption and desorption of $\mathrm{B}$ at equilibrium and it is, thus, an affinity term related to bonding energy $\left(\mathrm{L} \mathrm{mg}^{-1}\right)$.

The parameters $\mathrm{b}$ and $\mathrm{k}$ were calculated using the linear transforming $\mathrm{c} / \mathrm{x}=\mathrm{c} / \mathrm{b}+1 /(\mathrm{kb})$. Maximum buffering capacity (MBC) of soils was also calculated as a product of adsorption maxima and affinity coefficient (Holford and Mattingly, 1976).

\section{Desorption Study}

The mixtures were re-suspended, centrifuged and $10 \mathrm{ml}$ of supernatant were removed for Boron estimation, at timely intervals. Boron desorbed was calculated as difference between amount of B at each step, and that in the previous step divided by 2 as dilution factor and expressed as percentage of adsorbed B at different added concentrations of Boron.

\section{Statistical Analysis}

Correlation analysis between various soil properties and available B is done. The Frendulich and Langmuir adsorption isotherm parameters were determined and their relationship with different soil properties was found out.

\section{RESULTS}

The initial soil properties of all major soil series were determined. The $\mathrm{pH}$ values varied from 6.6 in Sivasubramaniyapuram series to maximum of 7.84 in Killikulam series. The EC values ranged from $0.06 \mathrm{dS} / \mathrm{min}$ Sivasubramaniyapuram series to $0.4 \mathrm{dS} \mathrm{m}^{-1}$ in Vallanad series (Table1). The cation exchange capacity of the soils is measured in terms of centi mole proton per kg and it varied from 10.68 to 13.25 (Table1). The textural fractions of all soil series were estimated, and it indicated that the Manakarai, 
Killikulam and Sivasubramaiyapuram comes under sandy Clay loam and the series Ezhuthaniyuthu and Vallanad comes under sandy loam texture(Table1). Available Boron content extracted through hot water and estimated using Azomethane-H method varied from $0.14 \mathrm{mg} \mathrm{kg}^{-1}$ to $0.25 \mathrm{mg} / \mathrm{kg}$ (Table1).

Correlation between the soil properties was determined. Soil $\mathrm{pH}$ is positively correlated with other soil properties considered, except the silt and sand percentage. Similarly, the EC values are also positively correlated with other soil properties except that of silt and sand percentage. The CEC of the soils was negatively correlated with sand percent alone. The organic carbon and organic matter content has negative correlation with sand fractions. From the textural class results, the negative correlation among different textural fractions can be visualized. There is a significant positive correlation between $\mathrm{pH}$ and $\mathrm{EC}\left(\mathrm{r}^{2}=\right.$ 0.97), $\mathrm{pH}$ and Boron $\left(\mathrm{r}^{2}=0.87\right), \mathrm{OC}$ and Clay $\left(\mathrm{r}^{2}=0.97\right), \mathrm{OM}$ and Clay $\left(\mathrm{r}^{2}=0.96\right)$ and a significant negative correlation between CEC and Sand, and Boron and Sand percent (Table2).

Available boron content of the soil formed positive correlations with $\mathrm{pH}, \mathrm{EC}, \mathrm{CEC}, \mathrm{OC}, \mathrm{OM}$ and Clay percent whereas it is negatively correlated with silt and sand percent (Table2).

Adsorption experiment was carried out with all major soil series by using different concentrations of boron. When no boron was introduced, adsorption ranged from $0.08 \mathrm{mg} \mathrm{kg}^{-1}$ to a maximum of $0.20 \mathrm{mg} \mathrm{kg}^{-1}$. The boron adsorption of soils increased with increasing concentrations. When a maximum of $50 \mathrm{mg} \mathrm{kg}^{-1}$ of boron were introduced, a maximum of $28 \mathrm{mg} \mathrm{kg}^{-1}$ was adsorbed. Percentage of adsorption varied from $48 \%$ to a maximum of $84 \%$. The maximum adsorption was observed in Sivasubramaniyapuram series with a average of $64 \%$ adsorption of applied boron and minimum adsorption was found with Vallanad series with an average of $57 \%$ adsorption.(Figure 3 )

Correlation between the considered soil properties and the constants of Frendulich and Langmuir Adsorption isotherm was carried out. Among the Frendulich constants, the Intercept(a) was positively correlated with most properties with the exception of silt and sand percent and the slope $(1 / \mathrm{n})$ formed negative correlation with all other properties, except silt percent. The Langmuir constants b, k, b*k formed positive correlations with all other properties except silt and sand percent (Table4).

The $\mathrm{R}^{2}$ values of Frendulich adsorption isotherm were 0.77 to 0.88 , which showed a high suitability of application of Frendulich isotherm to boron adsorption (Table5). The maximum bonding energy of $1.20\left(\mathrm{~L} \mathrm{mg}^{-1}\right)$ was found with Sivasubramaniyapuram series which showed higher percentage of adsorption earlier. The $\mathrm{R}^{2}$ values of Langmuir adsorption isotherm were 0.12 to 0.28 , which indicated the lesser suitability of its application to boron adsorption. Based on Langmuir adsorption the adsorption maxima was higher for Ezhuthaniyuthu with $98\left(\mathrm{mg} \mathrm{g}^{-1}\right)$ and lower for $72.58\left(\mathrm{mg} \mathrm{g}^{-1}\right)$. According to Langmuir isotherm, maximum bonding energy was observed for Killikulam series, which is on par with Sivasubramaniyapuram series. The maximum buffering capacity was found with Sivasubramaniyapuram series followed by Killikulam series (Table6).

The desorption study revealed that the desorption was minimum with Sivasubramaniyapuram series with an average among time as $9.69 \mathrm{mg} \mathrm{kg}^{-1}$ followed by Killikulam series with $9.73 \mathrm{mg} \mathrm{kg}^{-1}$ and maximum desorption was found with vallanad series with the average of $10.6 \mathrm{mg} \mathrm{kg}^{-1}$ (Table7). In general, among all the series the desorption was maximum initially, and it slowed down as time proceeds. The series with maximum adsorption showed lower desorption and vice-versa. (Figure $3 \& 4$ ). 
Boron Adsorption and Desorption Study: Correlation between Soil Properties,

Table 1: Soil Properties of Major Soil Series of Tamirabharani Tract of Tamil Nadu Chosen for Adsorption Study

\begin{tabular}{|c|c|c|c|c|c|c|c|c|c|c|}
\hline Series Name & pH & $\begin{array}{l}\text { Ec } \\
(d S \\
\left.m^{-1}\right)\end{array}$ & $\begin{array}{c}\text { CEC } \\
(\text { c mol } \\
++ \\
\left(p^{+}\right) \mathrm{kg} \\
1 \\
\left.{ }^{\prime}\right)\end{array}$ & $\underset{\%}{\text { Clay }}$ & $\begin{array}{l}\text { Silt } \\
\%\end{array}$ & $\begin{array}{c}\text { Fine } \\
\text { sand } \\
\%\end{array}$ & $\begin{array}{l}\text { Coarse } \\
\text { sand \% }\end{array}$ & $\begin{array}{c}\text { Organic } \\
\text { carbon } \\
(\%)\end{array}$ & $\begin{array}{c}\text { Organic } \\
\text { matter } \\
(\%)\end{array}$ & $\begin{array}{c}\text { Soil } \\
\text { available } \\
\text { Boron } \\
\left(\mathrm{mg} \mathrm{kg}^{-1}\right)\end{array}$ \\
\hline Manakarai & 7.04 & 0.08 & 11.63 & 31.40 & 12.40 & 31.70 & 24.50 & 0.54 & 0.936 & 0.15 \\
\hline Killikulam & 7.84 & 0.19 & 13.25 & 32.56 & 13.03 & 33.23 & 21.18 & 0.53 & 0.918 & 0.23 \\
\hline Ezhuthaniyuthu & 7.58 & 0.10 & 10.10 & 19.83 & 13.28 & 40.53 & 26.28 & 0.50 & 0.866 & 0.17 \\
\hline Vallanad & 7.16 & 0.40 & 10.68 & 19.50 & 13.20 & 40.10 & 25.70 & 0.59 & 1.020 & 0.14 \\
\hline Sivasubramaniyapuram & 8.61 & 0.06 & 11.30 & 29.38 & 15.95 & 37.03 & 27.53 & 0.48 & 0.831 & 0.25 \\
\hline
\end{tabular}

Table 2: Relationship Among Different Soil Properties and Soil Available Boron

\begin{tabular}{|l|c|c|c|c|c|c|c|c|c|}
\hline & pH & EC & CEC & OC & OM & Clay & Silt & Sand & Boron \\
\hline pH & 1 & & & & & & & & \\
\hline EC & 0.97 & 1 & & & & & & & \\
\hline CEC & 0.385 & 0.48 & 1 & & & & & & \\
\hline OC & 0.336 & 0.256 & 0.382 & 1 & & & & & \\
\hline OM & 0.336 & 0.256 & 0.369 & 0.999 & 1 & & & & \\
\hline Clay & 0.389 & 0.349 & 0.602 & 0.967 & 0.964 & 1 & & & \\
\hline Silt & -0.336 & -0.255 & 0.004 & 0.863 & 0.864 & -0.752 & 1 & & \\
\hline Sand & -0.044 & -0.104 & -0.891 & -0.279 & -0.271 & -0.477 & -0.216 & 1 & \\
\hline Boron & 0.868 & 0.839 & 0.514 & 0.739 & 0.732 & 0.777 & -0.687 & -0.783 & 1 \\
\hline
\end{tabular}

Table 3: Amount of Boron Adsorbed with Different Concentration of Added Boron

\begin{tabular}{|c|c|c|c|c|c|}
\hline \multirow{2}{*}{$\begin{array}{c}\text { Boron Concentration } \\
\left(\mathbf{m g ~ L}^{-1}\right)\end{array}$} & \multicolumn{5}{|c|}{ Adsorbed Boron $\left(\mathbf{m g ~ k g}^{-\mathbf{1}}\right)$} \\
\cline { 2 - 6 } & Manakarai & Killikulam & Ezhuthaniyuthu & Vallanad & Sivasubramaniyapuram \\
\hline $\mathbf{0}$ & 0.10 & 0.18 & 0.12 & 0.08 & 0.20 \\
\hline $\mathbf{2 . 5}$ & 1.30 & 1.33 & 1.26 & 1.24 & 1.20 \\
\hline $\mathbf{5 . 0}$ & 3.21 & 3.25 & 3.25 & 3.31 & 3.47 \\
\hline $\mathbf{1 0 . 0}$ & 7.23 & 7.37 & 5.17 & 5.22 & 8.37 \\
\hline $\mathbf{2 0 . 0}$ & 15.1 & 14.9 & 15.0 & 14.8 & 14.9 \\
\hline $\mathbf{3 0 . 0}$ & 18.1 & 17.9 & 16.9 & 16.8 & 18.5 \\
\hline $\mathbf{4 0 . 0}$ & 22.6 & 22.4 & 21.3 & 21.0 & 23.1 \\
\hline $\mathbf{5 0 . 0}$ & 27.2 & 26.9 & 25.6 & 25.3 & 27.8 \\
\hline
\end{tabular}

Table 4: Correlation coefficients (r-values) between Adsorption Equation Parameters and Soil Characteristics

\begin{tabular}{|c|c|c|c|c|c|}
\hline Soil properties & \multicolumn{2}{|c|}{ Frendulich constants } & \multicolumn{3}{c|}{ Langmuir Constants } \\
\hline & $\mathbf{A}$ & $\mathbf{1 / n}$ & $\mathbf{b}$ & $\mathbf{k}$ & $\mathbf{b x k}$ \\
\hline $\mathbf{p H}$ & 0.45 & -0.54 & 0.49 & 0.48 & 0.52 \\
\hline EC & 0.4 & -0.51 & 0.51 & 0.57 & 0.58 \\
\hline CEC & 0.5 & -0.19 & 0.88 & 0.97 & 0.94 \\
\hline OC & 0.98 & -0.82 & 0.78 & 0.52 & 0.65 \\
\hline OM & 0.97 & -0.82 & 0.77 & 0.5 & 0.64 \\
\hline Clay & 0.98 & -0.77 & 0.91 & 0.71 & 0.82 \\
\hline Silt & -0.85 & 0.99 & -0.46 & -0.21 & -0.33 \\
\hline Sand & -0.31 & -0.13 & -0.78 & -0.72 & -0.77 \\
\hline
\end{tabular}


Table 5: Frendulich Adsorption Isotherm Constants for Major Soil Series of Tamirabharani Tract

\begin{tabular}{|l|c|c|c|c|}
\hline \multicolumn{1}{|c|}{ Series name } & $\mathbf{R}^{\mathbf{2}}$ & Intercept (a) & Slope(b) & Bonding Energy (L mg $\mathbf{~}^{\mathbf{1}}$ ) \\
\hline Manakarai & 0.88 & 0.283 & 0.920 & 1.09 \\
\hline Killikulam & 0.88 & 0.304 & 0.895 & 1.12 \\
\hline Ezhuthaniyuthu & 0.88 & 0.200 & 0.921 & 1.09 \\
\hline Vallanad & 0.88 & 0.202 & 0.913 & 1.10 \\
\hline Sivasubramaniyapuram & 0.77 & 0.395 & 0.830 & 1.20 \\
\hline
\end{tabular}

Table 6: Langmuir Adsorption Isotherm Constants for Major Soil Series of Tamirabharani Tract

\begin{tabular}{|c|c|c|c|c|c|c|}
\hline Series Name & $\mathbf{R}^{2}$ & $\begin{array}{c}\text { Slope } \\
(1 / n)\end{array}$ & $\begin{array}{l}\text { Intercept } \\
\quad \text { (a) }\end{array}$ & $\begin{array}{l}\text { Adsorption Maxima } \\
\qquad\left(\mathrm{mg} \mathrm{g}^{-1}\right)(\mathrm{b})\end{array}$ & $\begin{array}{l}\text { Bonding Energy } \\
\quad\left(\mathrm{L} \mathrm{mg}^{-1}\right)(\mathrm{k})\end{array}$ & $\begin{array}{c}\text { Maximum } \\
\text { Buffering } \\
\text { Capacity }\end{array}$ \\
\hline Manakarai & 0.2 & 0.530 & 0.012 & 85.02 & 0.022 & 1.89 \\
\hline Killikulam & 0.28 & 0.508 & 0.014 & 72.58 & 0.027 & 1.97 \\
\hline Ezhuthaniyuthu & 0.14 & 0.670 & 0.010 & 98.09 & 0.015 & 1.49 \\
\hline Vallanad & 0.16 & 0.671 & 0.011 & 90.62 & 0.016 & 1.49 \\
\hline Sivasubramaniyapuram & 0.12 & 0.496 & 0.012 & 81.82 & 0.025 & 2.02 \\
\hline
\end{tabular}

Table 7: Amount of $\mathrm{B}$ desorbed from the Soils in $0.01 \mathrm{M} \mathrm{CaCl} \mathrm{C}_{2}$ Solution with respect to time in Major Soil Series of Tamirabharani Tract

\begin{tabular}{|c|c|c|c|c|c|}
\hline \multirow{2}{*}{ Time (hours) } & \multicolumn{5}{|c|}{ Boron desorbed (mg kg $\mathbf{~}^{-1}$ ) } \\
\cline { 2 - 6 } & Manakari & Killikulam & Ezhuthaniyuthu & Vallanad & Sivasubramaiyapuram \\
\hline $\mathbf{1}$ & 8.90 & 8.60 & 9.15 & 9.22 & 8.08 \\
\hline $\mathbf{2}$ & 9.21 & 9.11 & 10.01 & 10.32 & 9.60 \\
\hline $\mathbf{4}$ & 10.40 & 10.01 & 10.98 & 11.06 & 10.21 \\
\hline $\mathbf{6}$ & 10.60 & 10.42 & 11.02 & 11.12 & 10.26 \\
\hline $\mathbf{8}$ & 10.80 & 10.53 & 11.18 & 11.19 & 10.31 \\
\hline
\end{tabular}

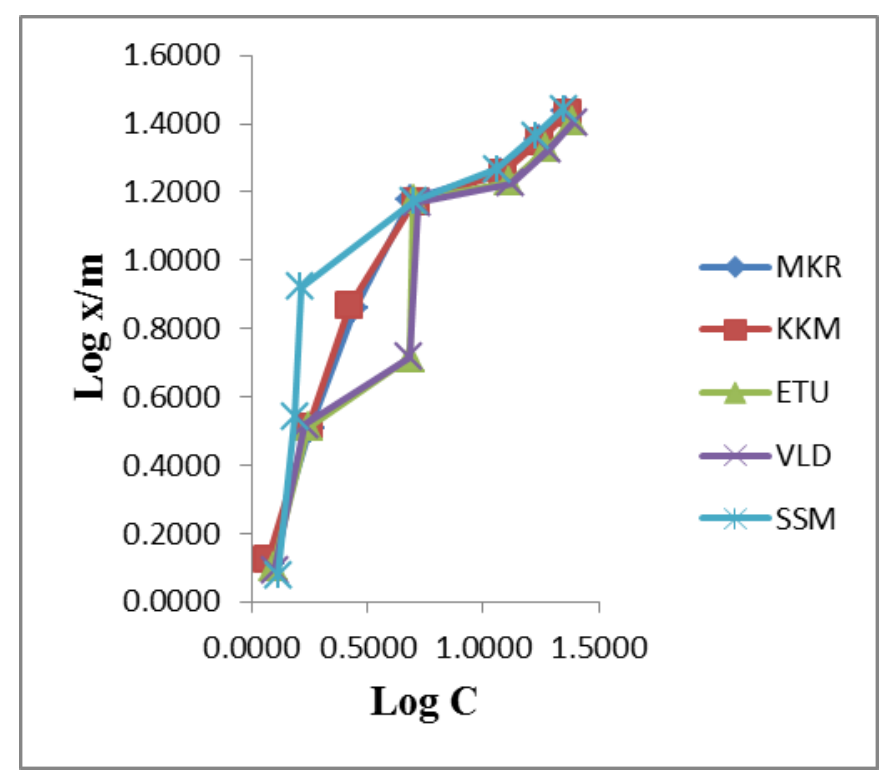

Figure 2:Frendulich Adsorption Isotherm for various Soil Series. 


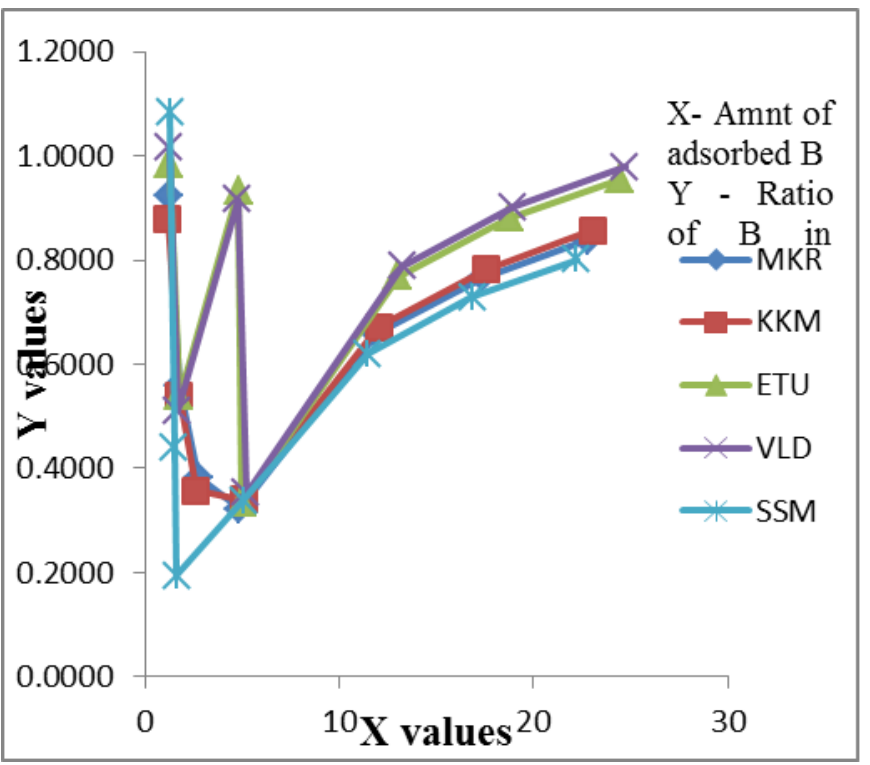

Figure 3: Langmuir Adsorption Isotherm for various Soil Series.

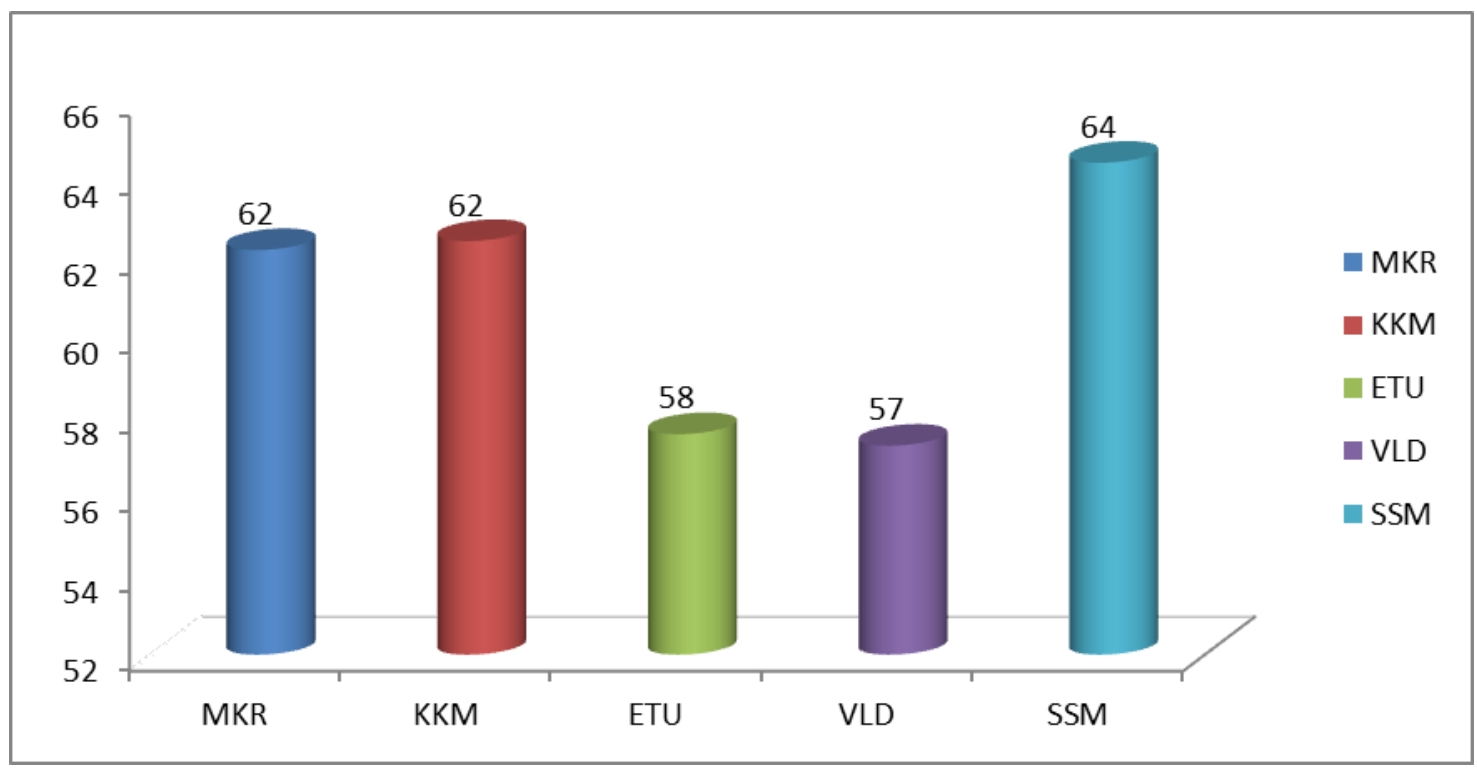

Figure 4: Average Percentage of Adsorption by various Soil Series.

\section{DISCUSSIONS}

Sand percent of the soil formed negative correlation with all of the soil properties analyzed, as higher sand content has a negative impact on most soil properties. The positive correlation abtained between $\mathrm{pH}$ and OC has been supported by Kundu et. al., (2016).

TheSoil $\mathrm{pH}$ showed a significant positive correlation $\left(\mathrm{r}^{2}=0.86\right)$ with available boron content of soil, and this result is supported by many workers of boron adsorption which includes Kumari et. al.,(2017) Mathur \& Sudan, (2011), Sarkar et. al., (2008), Elrashidi \& O’Connor, (1982), Tili et. al., 2019, Sarkar et. al., 2008, whereas Tili et. al., (2019) concluded that available Boron is positively correlated with $\mathrm{pH}$ upto a $\mathrm{pH}$ of 9 and decreases thereafter. On a contrary, certain authors like Hara \& Tamai, (2012), Arora \& Chahal (2005) and Kundu et. al., (2016 )indicated negative correlation between available Boron and soil pH. The 
obtained significant positive correlation between EC and Boron is in line with the conclusions ofArora \& Chahal, Tili et. al.,(2019) and Mathur \& Sudan(2011). This may be due to the fact that increasing salt concentrations of soil increases boron availability. Clay content in soil has a major effect on available Boron. A high positive correlation $\left(r^{2}=0.78\right)$ between clay content and available boron was obtained. This conclusion may be attributed to the greater capacity of clay fractions to retain and release boron into soil solution. This positive relationship has been proved by Hara \& Tamai, Tili et. al., and Shorrocks.

The Cation exchage capacity increases the boron availability and hence a positive relationship has been obtained $\left(r^{2}=\right.$ 0.51 ), and this is supported byArora \& Chahal. Increase in organic carbon increased the availability of most of the soil properties and also with boron. This is proven by high positive correlation $\left(r^{2}=0.73\right)$ between organic carbon and available Boron. This is evident with the results of various workers likeMathur \& Sudan(2011), Kundu et. al., Sarkar et. al., Raza et. al., and Elrashidi \& O'Connor. A negative correlation between silt and boron content was obtained which is in contrary with the results ofTili et. al., who concluded positive relationship between siltand available Boron. Sand percentage had a negative relationship with other soil properties especially with available Boron $\left(r^{2}=0.78\right)$.

Boron adsorption formed a positive relationship with $\mathrm{pH}$ and similar results were obtained with Tili et. al., and Datta \& Bhadoria. High organic carbon content showed higher adsorption of boron. Boron adsorption increases with increasing cation exchange capacity. Adsorption of boron increases with clay content as adsorption increases with increasing fineness of soil fractions and decreases with increasing sand content. This is in accordance with the results obtained by Tili et. al., and Datta \& Bhadoria. The adsorption of boron increased with increasing concentrations of added boron. Boron desorption is in inverse relation with adsorption of boron. Moreover boron desorption forms positive correlation with with Organic carbon as well as CEC.

The adsorption isotherm parameters like Fendulich ' $a$ ', Frendulich ' $1 / \mathrm{n}$ ', Langmuir ' $b, \mathrm{k}, \mathrm{b}$ *k' were correlated with soil properties. Frendulich 'a' formed positive correlation with all other properties except silt and boron. The positive correlation of Frendulich 'a' with clay and CEC has been proved by - Chaudhary \&Shukla (2004). Frendulich ' $1 / \mathrm{n}$ ' formed negative correlation with all other properties except silt percentage. The negative correlation between organic carbon and $1 / \mathrm{n}$ is in contrary with Chaudhary \&Shukla (2004), who concluded a positive relationship. All the isotherm parameters formed positive correlations with other soil properties except with silt and sand percentage. This is in accordance with Chaudhary \&Shukla (2004), who showed a positive relationship between Langmuir adsorption isotherm parameters and CEC. Frendulich isotherm parameters formed higher $\mathrm{r}^{2}$ values ( 0.77 to 0.88$)$ with the studied soil series than Langmuir parameters (0.12 to 0.28$)$. This proves that Frendulich adsorption is best suited for boron adsorption than Langmuir adsorption isotherm. This is also in line with the conclusions of Chaudhary \&Shukla (2004).

\section{CONCLUSIONS}

Soil available boron (Hot water soluble) content is positively correlated with certain soil parameters like pH, EC, OC, Clay and $\mathrm{CEC}$, whereas it is negatively correlated with silt and sand percentage. Boron adsorption increased with increasing concentrations of boron upto 50ppm, and it also depends on certain parameters like pH EC CEC Clay etc., Desorption of boron is rapid initially, and it slows down with time. The Frendulich adsorption isotherm is best suited to explain boron adsorption than Langmuir adsorption isotherm. 
Boron Adsorption and Desorption Study: Correlation between Soil Properties, Available Boron and the Adsorption Isotherm Parameters

\section{REFERENCES}

1. A EM, A OCG. Boron sorption and desorption in soils. Journal of Soil science society of America. 1982;46:27-31.

2. Alleoni LRF, de Camargo OA. Boron adsorption in soils from the State of Sao Paulo, Brazil. Pesquisa Agropecuaria Brasileira. 2000;35(2):413-21.

3. Arora S, S CD. Available boron content in some benchmark soils of Punjab under differet moisture regimes in relation to soil characteristcs. Journal of Agropedology. 2005(15 (2)):90 - 4.

4. Chaudhary D, M SL. Boron adsorption and desorption in arid soils of India. Journal of Agrochimica. 2004;47:3-4.

5. Datta SP, Bhadoria PBS. Boron adsorption and dsorption in some acid soils of Wet Bengal, India. Journal of Plant nutrition and soil science. 1999:183 - 91.

6. Datta SP, Rattan RK, Suribabu K, Datta SC. Fractionation and colorimetric determination of boron in soils. Journal of Plant Nutrition and Soil Science. 2002;165(2):179-84.

7. Dey A, Dwivedi BS, Meena MC, Datta SP. Adsorption - deorption of boron in major sils of India. Journal of Indian Society of Soil Science. 2013;61:179 - 87 .

8. Diana G, Beni C, Marconi S. Comparison of isotherm equations for boron adsorption and desorption on soils with fertilizer applications. Agrochimica. 2009;53(4):260-72.

9. Goldberg S, Corwin DL, Shouse PJ, Suarez DL. Prediction of boron adsorption by field samples of diverse textures. Soil Science Society of America Journal. 2005;69(5):1379-88.

10. Krishnasamy R, Surendran U, Sudhalakshmi C, Raja ME. Boron adsorption on semiarid soils of Tamil Nadu, India. Xu F, Goldbach HE, Brown PH, Bell RW, Fujiwara T, Hunt CD, et al., editors2007. 331-+ p.

11. Kumari K, Nazir G, Singh A, Kumar P. Studies on Boron Fractions with Different Physico-Chemical Properties of Cultivated Soils of Himachal Pradesh, India. International Journal of Current Microbiology and Applied Sciences. 2017;6(6):1547-55.

12. Kundu D, Rubina $K$, Saha $S$, Thingujam U, Hazra GC. Boron availability in relation to some importanat soil chemical properties in acid soils of Cooch Behar district, West Bengal. Journal of Applied and Natural Science. 2017;9 (4):2400 - 3.

13. Mathur R, Sudan P. Relationship and distribution of vrious forms of boron with different physio chemical properties of soil in bianer district. Journal of chemical and Pharmaceutical Research. 2011(3(3)):290-4.

14. Saltali K, Bilgili AV, Tarakcioglu C, Durak A. Boron adsorption in soils with different characteristics. Asian Journal of Chemistry. 2005; 17(4):2487-94.

15. Sarkar D, Mandal B, Kundu MC, Bhat JA. Soil Properties Influence Distribution of Extractable Boron in Soil Profile. Communications in Soil Science and Plant Analysis. 2008;39(15-16):2319-32.

16. Shorrocks VM. The occurance and correction of boro deficiency. Plant and Soil. 1997;193(2):121-48.

17. Tlili A, Dridi I, Attaya R, Gueddari M. Boron Characterization, Distribution in Particle-Size Fractions, and Its Adsorption-Desorption Process in a Semiarid Tunisian Soil. Journal of Chemistry. 2019;2019:1-8. 
